\title{
RAPD Analysis of Colletotrichum capsici Causing Anthracnose of Chilli in Madhya Pradesh, India
}

\author{
Ashish Bobade ${ }^{\text {** }}$, P. P. Shastry ${ }^{2}$, Ajay Kumar $^{3}$, R. K. Pandya ${ }^{3}$, \\ Sushma Tiwari ${ }^{4}$ and Reeti Singh ${ }^{3}$
}

${ }^{1}$ Krishi Vigyan Kendra, B.M. College of Agriculture, Khandwa-450001(MP), India

${ }^{2}$ Zonal Agricultural Research Station, Khargone-451001(MP), India

${ }^{3}$ Department of Plant Pathology, College of Agriculture, Gwalior-474002 (M.P.), India

${ }^{4}$ Department of Plant Breeding and Genetics, College of Agriculture, Gwalior-474002 (M.P.), India

*Corresponding author

\section{A B S T R A C T}

Keywords

Chilli,

Colletotrichum

capsici,

Pathogenicity,

RAPD, Molecular

variability

Article Info

Accepted:

04 September 2019

Available Online:

10 October 2019
In the present investigation an attempt was carry out to test the pathogenicity of the sixteen isolates of $C$. capsici obtained from different districts of Madhya Pradesh on ripe and green chilli by pin prick method and the genetically variation of these isolates was also detected by Random Amplified Polymorphic DNA (RAPD) technique. On ripe chilli, significantly maximum anthracnose incidence was recorded in BHP-1 (56.60\%) and minimum anthracnose incidence was recorded in $\mathrm{CHN}-2(33.80 \%)$ whereas on green chilli, significantly maximum anthracnose incidence was recorded in JHB-2 $(89.60 \%)$ while minimum anthracnose incidence was recorded in CHN-2 (61.40\%). For genetic variability, two primers were used which produced 32 scorable bands in which 23 bands were polymorphic and showed $72 \%$ polymorphism. Cluster analysis using the unweighted pair-group method with arithmetic average (UPGMA) clearly separated the isolates into two clusters (I and II), confirming the genetic diversity among the isolates of $C$. capsici. The genetical similarity coefficient value ranged from $0.335-0.992$ for OPD 07 primer across 7 isolates of $C$. capsici. RAPD analysis showed a clear difference in different isolates of $C$. capsici.

\section{Introduction}

In India, chilli is being grown in an area of $7,89,000$ ha with the production of $1,38,9000$ tonnes and yield of $1760 \mathrm{~kg} / \mathrm{ha}$ (Anonymous,
2016). Chilli (Capsicum annum L.) suffers from many diseases caused by fungi, bacteria, viruses, nematodes and also by abiotic stress. Among the fungal diseases, anthracnose/die back/ fruit rot caused by Colletotrichum 
capsici (Syd.) Butler and Bisby has become a most serious problem in all chilli-growing areas of India. Anthracnose reduces marketable yield from 10 to $80 \%$ (Poonpolgul, 2007). Although anthracnose appears on leaves and stems, it causes severe damage to mature fruits in the field, transit and storage (Mehrotra and Agrawal, 2003). Several species of Colletotrichum viz., C. capsici (Butler and Bisby), C. gloeosporioides (Penz.), C. acutatum (Sim- monds), $C$. atramentarium (Berk and Broome), $C$. dematium (Pers.) and C. coccoides (Wallr.), Glomerella cingulata (Stone- man) along with Altrenaria alternata (Keissler) have been reported as the causal agents of chilli fruit rot worldwide (Than et al., 2008). Mahmodi et al., (2014) reported the genetic diversity and differentiation of 50 Colletotrichum isolates from legume crops studied through multigene loci, RAPD and ISSR analyses. Prasad et al., (2013) reported the genetic variability in 10 commercial pepper varieties using RAPD markers. Analysis of genetic diversity is one step towards understanding the pathogen population. The objective of this study was to assess the diversity of Colletotrichum capsici infecting chilli in Northern region of Madhya Pradesh, India.

\section{Materials and Methods}

Isolation and identification of the Pathogens from infected chilli

Total 16 isolates were collected from eight districts (two blocks of each district) of Madhya Pradesh viz., Khandwa, Khargone, Burhanpur, Badwani, Dewas, Jhabua, Jabalpur and Chhindwara. Diseased samples were packed in sterile transparent polyethylene bags, labelled and transported to the Plant Pathology Laboratory. Three $5 \times 5 \mathrm{~mm}$ pieces of tissue were taken from the margins of infected tissue, surface-sterilized with $2.0 \%$ sodium hypochlorite solution for 30 seconds and rinsed three times with sterile water then placed on the surface of PDA and incubated at $25 \pm 2^{\circ} \mathrm{C}$ temperature. The growing edges of the hyphal mycelium developing from the diseased tissue discs were transferred aseptically to potato dextrose agar for reculturing. The identification of Colletotrichum was done based on the morphological and colony characteristics (Ellis, 1971; Barnett and Hunter, 1972).

\section{Molecular characterization of Colletotrichum capsici in chilli}

\section{Fungal DNA extraction}

For DNA extraction, each isolate of C. capsici was grown in 100-ml conical flasks, containing $30 \mathrm{ml}$ of potato dextrose broth for seven days at room temperature $\left(28 \pm 2^{\circ} \mathrm{C}\right)$. The mycelia were harvested by filtration and frozen in liquid nitrogen. Freeze-dried mycelium ( $1 \mathrm{~g}$ ) was ground to a fine powder using liquid nitrogen, and DNA was extracted according to standard protocols (Murray and Thompson, 1980) [8]. The genomic DNA was checked by agarose gel electrophoresis and stored at $-20^{\circ} \mathrm{C}$ for further use. In total, 10 random primers were used for RAPD analysis. PCR amplification was performed by using florescent labeled RAPD primers; (OPD-07: 5'TTGGCACGGG and OPL-05: 5'ACGCAGGCAC3') (Table 1). All the RAPD primers were purchased from Operon (Operon Biotechnologies, Cologne, Germany) and used as single primers. Amplification was performed in a $20 \mu$ l reaction volume consisting of $5 \mathrm{mM}$ each dNTPs, 20 pmol of primer, 0.5 $\mathrm{U}$ of Taq DNA polymerase (Bangalore Genei Pvt Ltd, Banglore, India) and $50 \mathrm{ng}$ of template.

\section{RAPD analysis}

The amplified fragments of each isolate were scored as 1 (present) or 0 (absent). 
Comigrating bands were considered homologous characters. Faint bands and bands showing variable levels of intensity were not considered for scoring.

\section{Statistical analysis}

A binary matrix was compiled using numerical system of multivariate analysis. The dendogram was constructed by the unweighted paired group method of arithmetic average (UPGMA) based on Jaccard's similarity coefficient with SHAN program of NT-sys, (Jaccard's, 1912).

\section{Results and Discussion}

Total 16 isolates were collected from eight districts (two blocks of each district) of Madhya Pradesh viz., Khandwa, Khargone, Burhanpur, Badwani, Dewas, Jhabua, Jabalpur and Chhindwara (Fig. 1, 2 and Table 2).

Pathogenicity of the sixteen isolates of $C$. capsici obtained from different districts of Madhya Pradesh was tested on ripe and green chilli by pin prick method. On ripe chilli, significantly maximum anthracnose incidence was recorded in BHP-1 (56.60 \%) except DWS-2 (56.40 \%), JHB-2 (54.40\%), BRW-2 $(53.40 \%)$ and $\mathrm{CHN}-1$ (53.00\%) followed by BHP-2 (52.00 \%), KNW-2 (51.00\%) and KGN-1 (49.40 \%), while minimum anthracnose incidence was recorded in $\mathrm{CHN}-2$ (33.80 \%) which was found at par with BRW$1(35.60 \%)$ and JBP-2 (36.40\%) followed by KGN-2 (38.20 \%), KNW-1 (40.40 \%), JBP-1 (43.80 \%), DWS-1 (44.40\%) and JHB-1 (46.60 \%). On green chilli, significantly maximum anthracnose incidence was recorded in JHB-2 (89.60 \%) followed by $\mathrm{CHN}-1$ $(84.40 \%)$ and DWS-2 (83.40 \%) while minimum anthracnose incidence was recorded in CHN-2 (61.40\%) which was found at par with BRW-1 (62.20\%), JBP-2 (63.60\%), KNW-1(63.80 \%), JBP-1 (64.40 \%) and
DWS-1 (64.40\%). Anthracnose disease is responsible for major economic losses in chilli production worldwide, especially in tropical and subtropical regions (Pakdeevaraporn et al., 2005). In this study, C. capsici was confirmed as the species responsible for chilli anthracnose in Northern Madhya Pradesh by pathogenicity test. The pathogenicity study showed that the behavior of $C$. capsici isolates were homogeneous with regard to disease symptoms. However, variation in virulence or the level of disease (measured quantitatively) within the isolates was observed. Differences in aggressiveness of $C$. capsici isolates have been reported previously by Taylor et al., (2007).

The molecular technique, RAPD was used to detect the genetical variation among the 16 isolates of $C$. capsici causing anthracnose in Chilli. Total 02 primers falling in OPD07 and OPL 05 were used to accesses molecular variation. Both primers produced 32 scorable bands. Among 32 bands 23 bands were polymorphic and level of polymorphism was $72 \%$ (Table 3).

The dendrogram constructed from the pooled data of primer OPD 07 indicated that, there were two major clusters I and II. Cluster I consist of five isolates sample 6, 7, 8, 9 and 2 while cluster II consist of two isolates sample sample 1 and 3 which is distinct and showed least similarity with all other isolate of $C$. capsici. The genetical similarity coefficient value ranged from $0.335-0.992$ for OPD 07 primer across 7 isolates of C. capsici (Fig. 3 and Table 4).

The dendrogram constructed from the pooled data of primer OPL 05 indicated that, there were two major clusters I and II. Cluster I consist of five isolates sample 6, 7, 8, 9 and 2 while cluster II consist of two isolates sample sample 1 and 3 which is distinct and showed least similarity with all other isolate of $C$. 
capsici. The genetical similarity coefficient value ranged from $0.634-0.995$ for OPL 05 primer across 9 isolates of C. capsiciI (Fig. 4, 5 and Table 5).

Phylogenetic analysis using RAPD marker data divided isolates of $C$. gloeosporioides from non-cultivated hosts into two separate clusters. Isolates from strawberry were interspersed within the cluster containing the isolates recovered from non-cultivated hosts.

Sharma et al., (2005) reported considerable pathogenic variation in $C$. capsici isolates collected from chilli-growing areas of Himachal Pradesh (HP), India.

Pathological and RAPD grouping of isolates suggested no correlation among the tested isolates of $C$. capsici. Ratanacherdchai et al., (2007) analysed 18 isolates of two species, $C$. gloeosporioides and $C$. capsici isolated from three varieties of chilli i.e. Chilli pepper $(C$. annuиm), Long cayenne pepper ( $C$. annuиm var acuminatum) and Bird's eye chilli ( $C$. frutescens) using RAPD analysis and reported a clear difference between $C$. gloeosporioides and $C$. capsici.

Ratanacherdchai et al., (2010) analysed the genetic diversity among isolates of $C$. gloeosporioides and $C$. capsici from Thailand by Inter simple sequence repeat (ISSR) analysis and reported that there were two distinct groups of $C$. gloeosporioides and $C$. capsici.

Furthermore, genetic diversity was correlated with geographical distribution, while there was no clear relationship between genetic diversity and pathogenic variability among the isolates of C. gloeosporioides and C. capsici. Pathogen diversity plays a major role in disease dynamics and consequently, in the success of disease management strategies, including the development of cultivars resistant to diseases. The results of the present study demonstrate that there is a high level of genetic diversity among isolates of $C$. capsici in Tamil Nadu. Pathogenicity tests revealed that these isolates expressed different levels of virulence.

The existence of molecular variability among isolates of $C$. capsici that differed in virulence was earlier established by Srinivasan et al., (2010) using RAPD markers.

The result of RAPD in the present investigation was further confirmed by sequence analysis of the ITS region which revealed $100 \%$ sequence similarity between the two $C$. capsici isolates of chilli and CI isolate of soybean. C. gloeosporoides, on the other hand, revealed significant sequence difference with $C$. capsici isolates CI. Freeman (2008) used sequence analysis of ITS region to establish similarity between Colletotrichum acutatum isolates from almond and strawberry.

Colletotrichum spp. causing anthracnose of chilli was identified as $C$. capsici. The phylogenetic grouping based on RAPD showed a relationship between clustering in dendrogram and geographical distribution of isolates.

However, the pathological and RAPD grouping of isolates was suggested on correlation among the tested isolates.

Therefore, RAPD markers are a useful method of studying genetic diversity in Colletotrichum spp. PCR-based technique like RAPD used in this study are rapid, reproducible and produce a large number of polymorphic bands.

Such techniques aid in the understanding of pathogen population dynamics, which can facilitate the development of effective control strategies. 
Table.1 Sequence of RAPD Primers used to study the Genetic variability among the isolates of Colletotrichum sp.

\begin{tabular}{|c|c|c|c|}
\hline S.N. & Primers & $\begin{array}{c}\text { Base sequence } \\
(\mathbf{5}, \underset{\mathbf{3}}{\mathbf{\prime}})\end{array}$ & Sample No. \\
\hline $\mathbf{1 .}$ & OPD 07 & TTGGCACGGG & $1,2,3,6,7,8$ \& 9 \\
\hline $\mathbf{2 .}$ & OPL 05 & ACGCAGGCAC & $4,5,10,11,12,13,14,15$ \& 16 \\
\hline
\end{tabular}

Table.2 Pathogenic variability among the isolates of $C$. Capsici

\begin{tabular}{|c|c|c|c|c|}
\hline \multirow[t]{2}{*}{ District } & \multirow[t]{2}{*}{ Block/Place } & \multirow[t]{2}{*}{ Isolates code } & \multicolumn{2}{|c|}{ Disease incidence $(\%)$} \\
\hline & & & Ripe Fruit & Green Fruit \\
\hline \multirow[t]{2}{*}{ Barwani } & Barwani & BRW-1 & $35.60(36.63)^{*}$ & $62.20(52.07)^{*}$ \\
\hline & Thikari & BRW-2 & $53.40(46.95)$ & $73.20(58.85)$ \\
\hline \multirow[t]{2}{*}{ Khargone } & Khargone & KGN-1 & $49.40(44.66)$ & $67.20(55.08)$ \\
\hline & Kasrawad & KGN-2 & $38.20(38.17)$ & $71.60(57.84)$ \\
\hline \multirow[t]{2}{*}{ Jabalpur } & Jabalpur & JBP-1 & $43.80(41.43)$ & $64.40(53.38)$ \\
\hline & Shahpura & JBP-2 & $36.40(37.03)$ & $63.60(52.90)$ \\
\hline \multirow[t]{2}{*}{ Burhanpur } & Burhanpur & BHP-1 & $56.60(48.79)$ & $71.20(57.57)$ \\
\hline & Khaknar & BHP-2 & $52.00(46.15)$ & $75.40(60.29)$ \\
\hline \multirow[t]{2}{*}{ Dewas } & Dewas & DWS-1 & $44.40(41.78)$ & $64.40(53.38)$ \\
\hline & Khategaon & DWS-2 & $56.40(48.69)$ & $83.40(66.01)$ \\
\hline \multirow[t]{2}{*}{ Jhabua } & Rama & JHB-1 & $46.60(43.05)$ & $74.40(59.66)$ \\
\hline & Petlawad & JHB-2 & $54.40(47.53)$ & $89.60(71.24)$ \\
\hline \multirow[t]{2}{*}{ Khandwa } & Chegaon Makhan & KNW-1 & $40.40(39.46)$ & $63.80(53.02)$ \\
\hline & Pandhana & KNW-2 & $51.00(45.57)$ & $74.80(59.93)$ \\
\hline \multirow[t]{2}{*}{ Chhindwara } & Sausar & CHN-1 & $53.00(46.72)$ & $84.40(66.77)$ \\
\hline & Pandhurna & CHN-2 & $33.80(35.54)$ & $61.40(51.60)$ \\
\hline \multicolumn{3}{|c|}{ SEm \pm} & 0.84 & 0.94 \\
\hline \multicolumn{3}{|c|}{ C.D. at $5 \%$} & 2.42 & 2.70 \\
\hline
\end{tabular}

Table.3 UPGMA average dendrogram constructed from RAPD data indicating the relationship among the isolates of $C$. capsici from chilli.

\begin{tabular}{|c|c|c|c|c|}
\hline Primers & $\begin{array}{c}\text { Monomorphic } \\
\text { bands }\end{array}$ & $\begin{array}{c}\text { Polymorphic } \\
\text { bands }\end{array}$ & $\begin{array}{c}\text { Total no. } \\
\text { of bands }\end{array}$ & $\begin{array}{c}\% \\
\text { Polymorphism }\end{array}$ \\
\hline OPD 07 & 04 & 05 & 09 & $56 \%$ \\
\hline OPL 05 & 05 & 18 & 23 & $78 \%$ \\
\hline Total & 09 & 23 & 32 & $72 \%$ \\
\hline
\end{tabular}


Table.4 Genetic similarity coefficient matrix for $C$. capsici from chilli based on RAPD analysis for primer OPD 07

\begin{tabular}{|c|c|c|c|c|c|c|c|}
\hline $\begin{array}{c}\text { Strain } \\
\text { Number }\end{array}$ & S_3 & S_6 & S_7 & S_2 & S_8 & S_9 & S_1 \\
\hline Sample_3 & 0 & & & & & & \\
\hline Sample_6 & 0.5851 & 0.0000 & & & & & \\
\hline Sample_7 & 0.5487 & 0.0175 & 0.0000 & & & & \\
\hline Sample_2 & 0.6200 & 0.0218 & 0.0185 & $2.220 \mathrm{E}-16$ & & & \\
\hline Sample_8 & 0.5553 & 0.0112 & 0.0076 & $1.747 \mathrm{E}-02$ & $2.220 \mathrm{E}-16$ & & \\
\hline Sample_9 & 0.6646 & 0.0281 & 0.0284 & $3.192 \mathrm{E}-02$ & $2.631 \mathrm{E}-02$ & $-2.220 \mathrm{E}-16$ & \\
\hline Sample_1 & 0.3172 & 0.3424 & 0.3249 & $3.742 \mathrm{E}-01$ & $3.426 \mathrm{E}-01$ & $3.953 \mathrm{E}-01$ & 0 \\
\hline
\end{tabular}

S- Sample

Table.5 Genetic similarity coefficient matrix for $C$. capsici from chilli based on RAPD analysis for primer OPL 05

\begin{tabular}{|c|c|c|c|c|c|c|c|c|c|}
\hline Strain Number & S_4 & S_5 & S_10 & S_11 & S_12 & S_13 & S_14 & S_15 & S_16 \\
\hline Sample_4 & 1.000 & & & & & & & & \\
\hline Sample_5 & 0.913 & 1.000 & & & & & & & \\
\hline Sample_10 & 0.845 & 0.949 & 1.000 & & & & & & \\
\hline Sample_11 & 0.634 & 0.744 & 0.809 & 1.000 & & & & & \\
\hline Sample_12 & 0.644 & 0.757 & 0.833 & 0.802 & 1.000 & & & & \\
\hline Sample_13 & 0.906 & 0.947 & 0.965 & 0.776 & 0.794 & 1.000 & & & \\
\hline Sample_14 & 0.867 & 0.957 & 0.995 & 0.801 & 0.826 & 0.973 & 1.000 & & \\
\hline Sample_15 & 0.788 & 0.878 & 0.974 & 0.805 & 0.826 & 0.932 & 0.968 & 1.000 & 1.000 \\
\hline Sample_16 & 0.781 & 0.862 & 0.958 & 0.790 & 0.806 & 0.917 & 0.953 & 0.994 & 1 \\
\hline S- Sanple & & & & & & & & \\
\hline
\end{tabular}

S- Sample 
Fig.1 Pathogenic variability among the isolates of $C$. Capsici

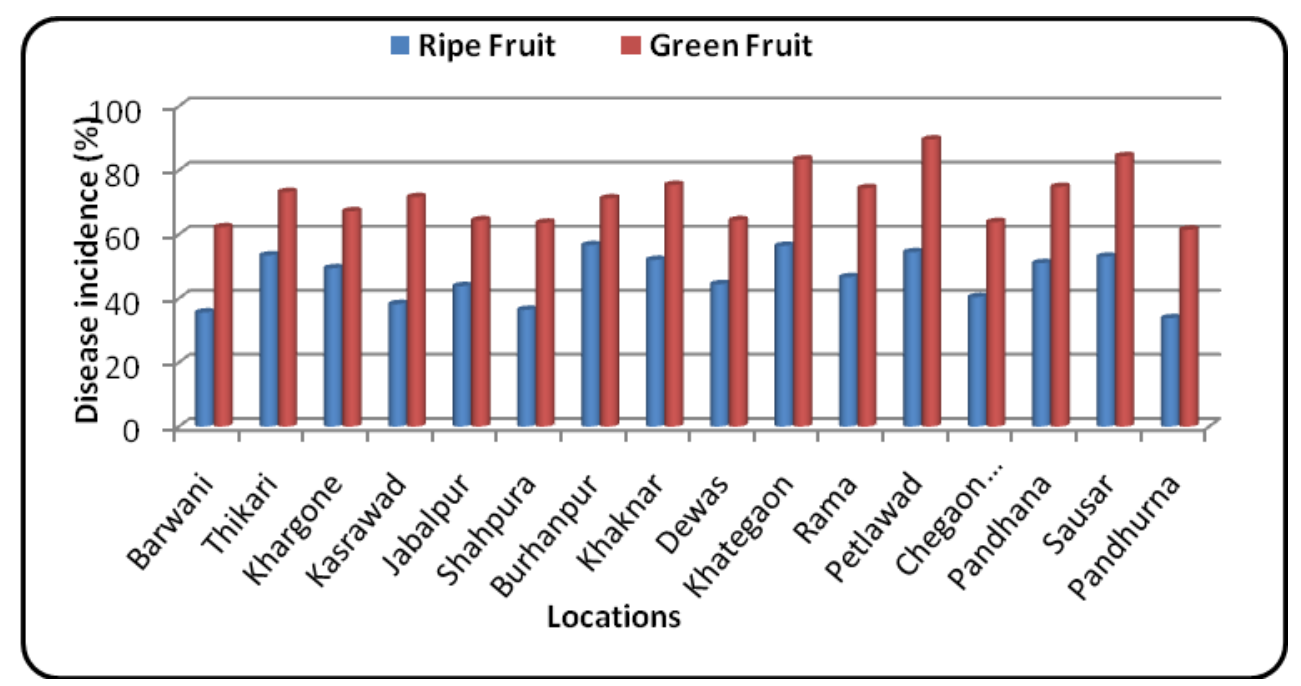

Fig.2 Symptoms produced by different isolates of C. capsici on green and red ripe fruits of chilli.

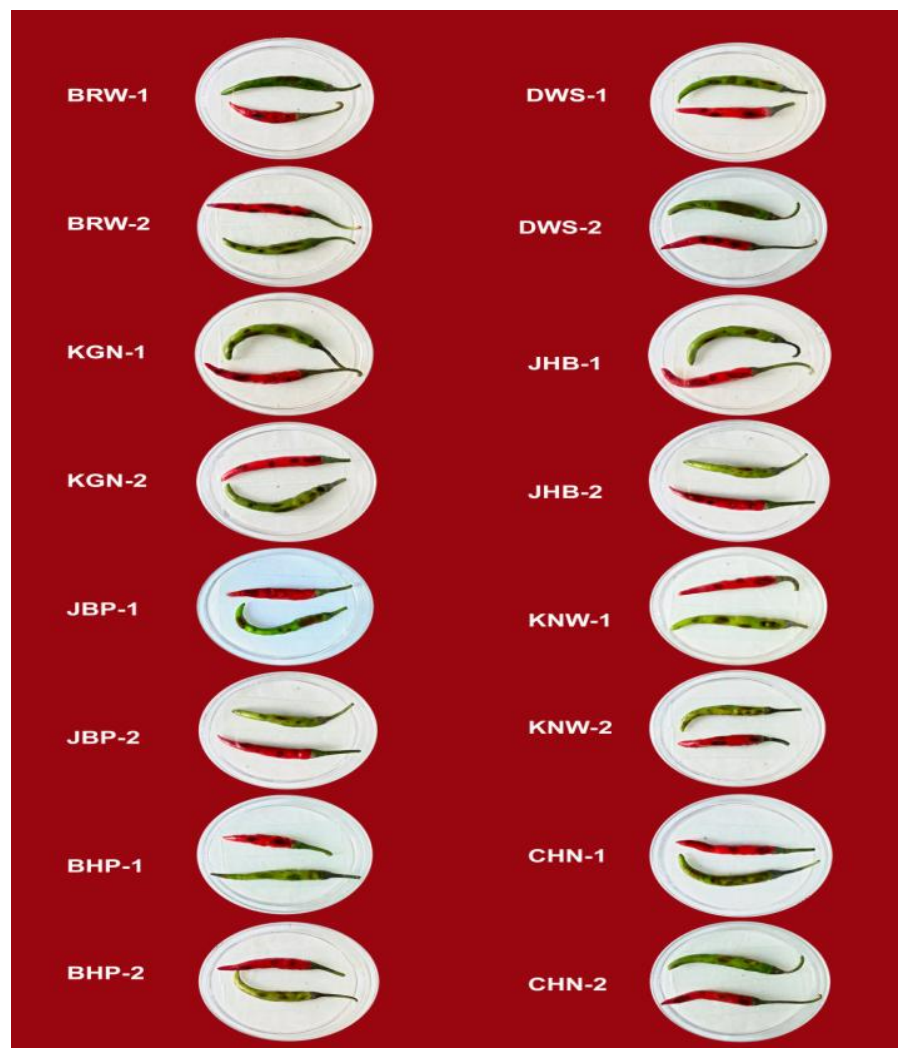


Fig.3 Dendrogram generated using Jaccard's similarity distance obtained from RAPD primers OPD 07.

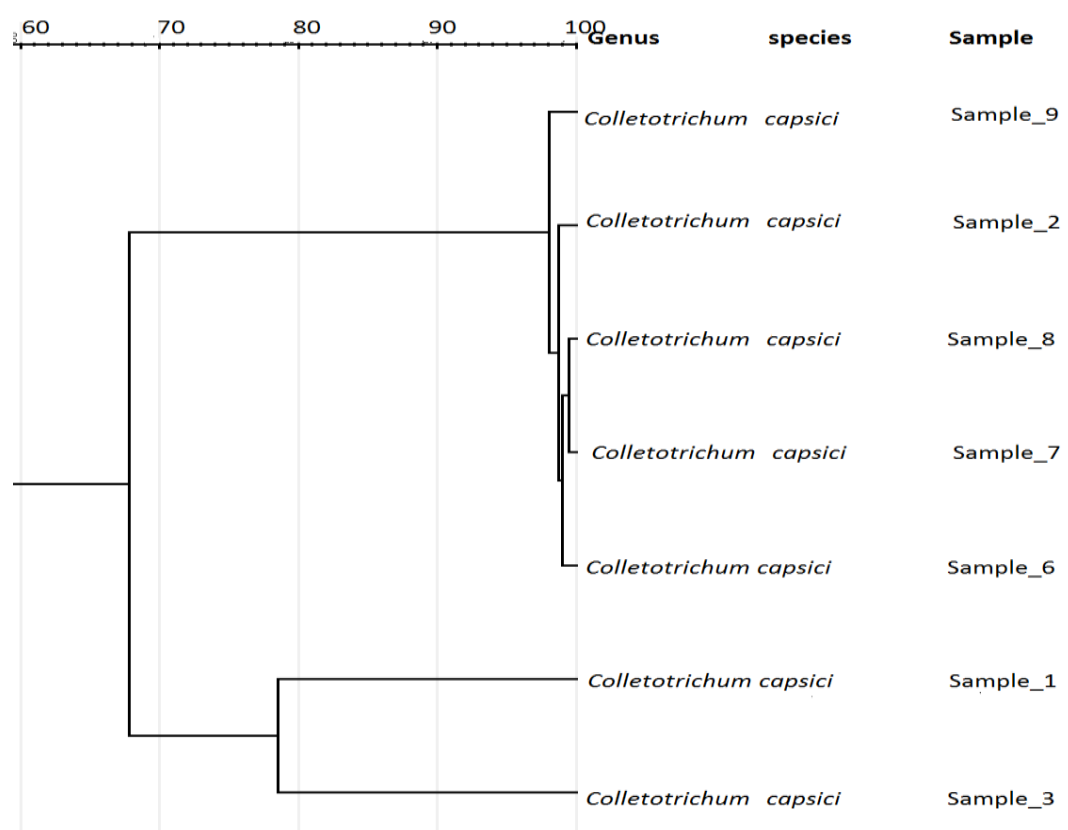

Fig.4 Dendrogram generated using Jaccard's similarity distance obtained from RAPD primers OPL 05.

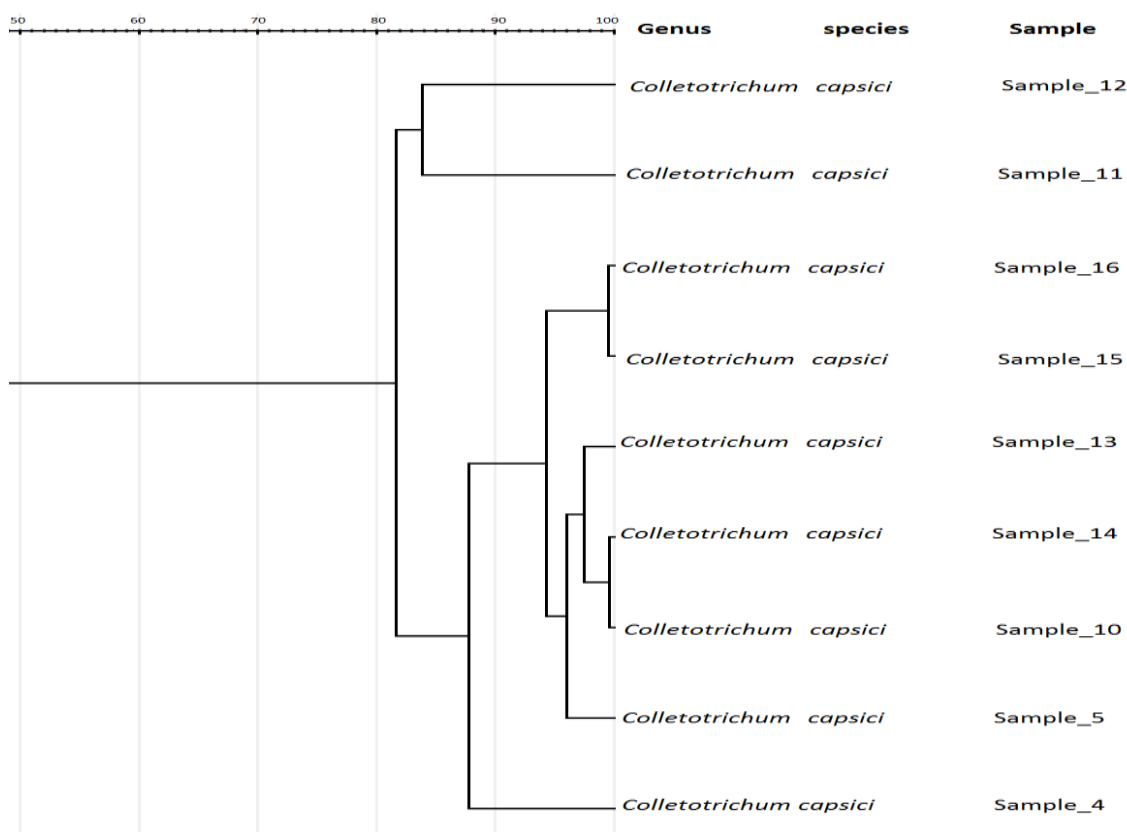


Fig.5 RAPD amplification banding pattern of primers OPL 05 and OPD 07 in Colletotrichum capsici isolates.

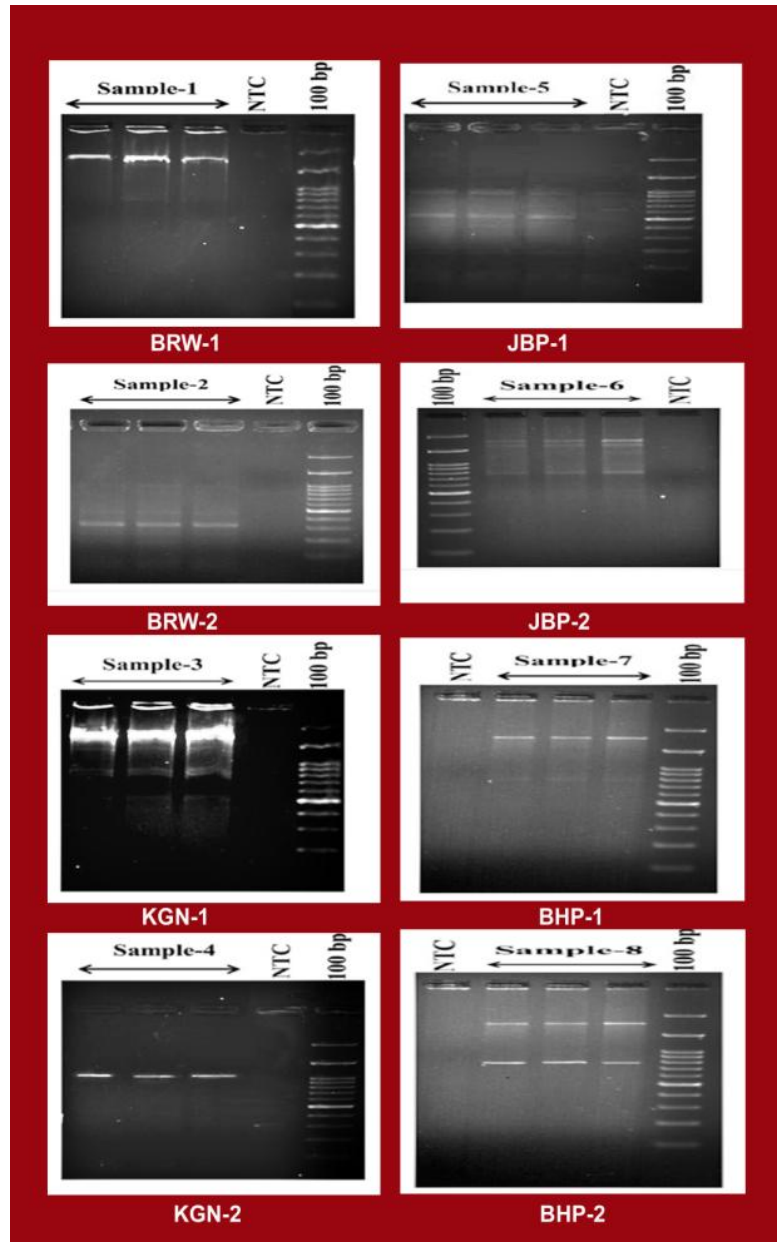

\section{Acknowledgement}

We are highly indebted to the authorities of the College of Agriculture, Gwalior to provide the lab facility to perform the research work and KPC Life Sciences, Calcutta, to provide the support and guidance in molecular study.

\section{Competing Interests}

Authors have declared that no competing interests exist.

\section{References}

Anonymous. 2016. Agricultural statistics at a glance, Directorate of Economics and

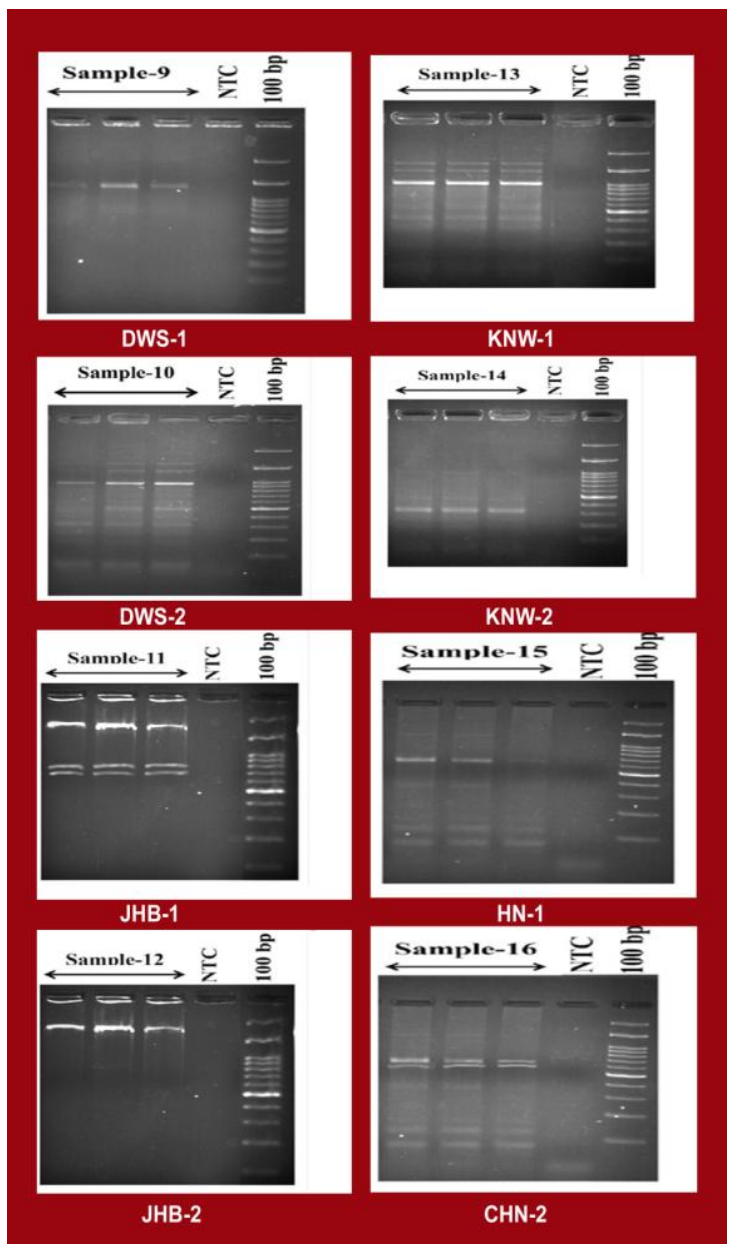

statistics, India.

Poonpolgul, S. and Kumphal S. 2007. Chilli/Pepper anthracnose in Thailand Country report. In: First International Symposium on chilli Anthracnose. Oh DG, Kim KT. (Eds) National Horticultural Research Institute, rural Development and Administration, Republic of Korea. 23.

Mehrota, R.S. and Aggarwal, A. 2003. Plant Pathology. $3^{\text {rd }}$ Eds., Tata McGrawHill, New Delhi Publication.

Than, P.P., Jeewon, R., Hyde, K.D., Pongsupasamit, S., Mongkolporn, O. and Taylor, P.W.J. 2008. Characterization and pathogenicity of Colletotrichum species associated with 
anthracnose disease on chilli (Capsicum spp.) in Thailand. Plant Pathology 57: 562-572.

Mahmodi, F., Kadir, J.B., Puteh, A., Pourdad, S.S., Nasehi, A., and Soleimani, N. 2014. Genetic diversity and Differentiation of Colletotrichum spp. Isolates Associated with Lequminosae using multigene Loci, RAPD and ISSR. Plant Pathology. J. 30(1):10-24.

Prsad, B., Khan, G. Chodhary, R., Venkataiah, P., Kumar, S., Christoper, R.T. 2013. DNA profiling of commercial chilli pepper (Capsicum annuum L.) varieties using random amplified polymorphic DNA (RAPD) markers. African Journal of Biotechnology. 2(30):4730-4735.

Sharma P.N., Kaur, M., Sharma, O.P., Sharma, P. and Pathania, A. 2005.Morphological, pathological and molecular variability in Colletotrichumcapsici the cause of fruit rot of chillies in the subtropical region of North-western India. Journal of Phytopathology. 153:232-237.

Ratanacherdchai, K., Wang, H.K., Lin, F.C. and Soytong, K. 2007. RAPD analysis of Colletotrichum species causing chilli anthracnose disease in Thailand. Journal of Agriculture Technology. 3:211-219.

Ratanacherdchai, K., Wang, H.K., Lin, F.C., Soytong, K. 2010. ISSR for comparison of cross-inoculation potential of Colletotrichum capsici causing chilli anthracnose. African Journal of Microbiology Research. 4: 76-83.

Taylor, P.W.J., Mongkolporn, O., Than, P.P., Montri, P., Ranathunge, N., Kanchanaudonkarn, C., Ford, R., Pongsupasamit, S., Hyde, K.D. 2007. Pathotypes of Colletotrichum spp. Infecting Chilli Peppers and Mechanisms of Resistance. In: Oh DG, Kim KT (Eds.), Abstracts of the First International Symposium on Chilli Anthracnose, National Horticultural Research Institute, Rural Development of Administration, Republic of Korea, p. 29.

\section{How to cite this article:}

Ashish Bobade, P. P. Shastry, Ajay Kumar, R. K. Pandya, Sushma Tiwari and Reeti Singh 2019. RAPD Analysis of Colletotrichum capsici Causing Anthracnose of Chilli in Madhya Pradesh, India. Int.J.Curr.Microbiol.App.Sci. 8(10): 303-312. doi: https://doi.org/10.20546/ijcmas.2019.810.031 